\title{
HISTORYK WE WSPÓŁCZESNYM ŚWIECIE. KILKA UWAG WOKÓt TEKSTU JANA POMORSKIEGO Polityzacja/mitologizacja historii, czyli w czym neuronauka (i metodologia) może pomóc badaczowi historii najnowszej?
}

\section{ABSTRACT}

\section{A HISTORIAN IN THE MODERN WORLD. SOME REMARKS ON JAN POMORSKI'S \\ QUESTION ABOUT THE POLITICIZATION/MYTHOLOGIZATION OF HISTORY OR HOW MIGHT NEUROSCIENCE (AND METHODOLOGY) SUPPORT THE RESEARCHERS OF THE CONTEMPORARY HISTORY}

Regarding how the present historians get involved in the debate on the politicization of the contemporary history, we can observe a superannuation of two models of historian: as a „cool scientist” and an „upholder of national values”. Apparently we could postulate in this moment the model of a historian as "a translator and mediator" between cultures, recognizing their "grammars", and his obligation to create the common social capital. Nevertheless the scientific reflection upon the politicization of history and the methodology of contemporary historiography is the matter in dispute. Therefore Pomorski's suggestion of the more complex cognitive approach in the historiographical research (and historical discourse) should be taken into consideration.

\section{KEYWORDS:}

contemporary historiography, the grammar of history, scientific reflection and axiology in the historical discourse, historian as a translator and a mediator, Collingwoodian historian. 
Erudycyjny i ważki, szczególnie w obecnej sytuacji, artykuł Jana Pomorskiego zachęca do dyskusji i polemik. Nie sposób w krótkim komentarzu odnieść się do wszystkich tez, inspiracji i kwestii postawionych przez Autora. W takiej sytuacji intencjonalnie wybieram jeden $\mathrm{z}$ wątków obecnych $\mathrm{w}$ artykule lubelskiego badacza, mianowicie jego uwagi poświęcone roli historyka akademickiego/ historyków akademickich w toczącej się w Polsce debacie dotyczącej dziejów najnowszych. Jest to temat szczególnie mi bliski, swego czasu rozważałem go w tekście publikowanym w 2006 roku'. Pisałem w nim m. in., że we współczesnej historiografii, czy szerzej kulturze, dezaktualizacji ulegają dwa wywodzące się z XIX stulecia wizerunki historyka - zimnego scjentysty i strażnika narodowych wartości. Ten pierwszy unika jednoznacznych deklaracji światopoglądowych, stroni od historiozofii, neguje potrzebę wypowiadania się na tematy współczesne. Pozostaje w „wieży z kości słoniowej”, wierząc, że „prawdziwa” nauka wolna jest od emocji, wymaga odpowiedniego dystansu czasowego, pracochłonnego i drobiazgowego rozważania bez końca wszelkich „za” $\mathrm{i}$,przeciw”. Ten drugi, niejako podświadomie, dokonuje arbitralnego wyboru. Odrzuca dyrektywę nakazującą mu zrozumienie opisywanych wydarzeń i postaci na rzecz ich usprawiedliwienia, gdy rzecz dotyczy preferowanego przez niego fragmentu narodowej przeszłości, lub potępienia, gdy z kolei nie mieszczą się one w świecie wyznawanych przez niego wartości. W praktyce historiograficznej prowadzi to albo do kreowania obrazu dziejów narodowych w duchu megalomanii narodowej i „chołoniewszczyzny”, lub też do takiej wizji przeszłości, w której Polska i Polacy są „ofiarami” wrogich im sił, zarówno tych, które mają charakter zewnętrzny np. obce mocarstwa, jak i tych rodzimych np. polscy Żydzi czy komuniści.

Jako lepiej przystający do naszych czasów, proponowałem wizerunek historyka „tłumacza”, pośrednika w dialogu między kulturami, pokazującego występujące między nimi różnice i podobieństwa. Opowiadałem się za dziejopisem kodyfikatorem wielkości danej kultury, narodu, rasy czy klasy, ale za badaczem mediatorem, wskazującym na rozliczne ograniczenia tkwiące w poznaniu przeszłości. Na koniec cytowałem Franklina Ankersmita i jego prowokacyjną uwagę, że obecnie winniśmy zamiast badać przeszłość zacząć o niej myśleć. Tezy te, z pewnymi zastrzeżeniami, gotowy jestem powtórzyć także obecnie.

R. Stobiecki, Historyk i jego rola we wspótczesnym świecie [w:] Gra i konieczność. Zbiór rozpraw z historii historiografii i filozofii historii red. G. Dominiak, W. Wrzosek, J.Ostoja-Zagórski, Bydgoszcz 2005, s. 49-60. Skrócona wersja tego tekstu Rola historyka we wspótczesnym świecie ukazała się w dodatku do pisma „Dziennik”: „Europa” 2005, nr 2/41/, s. 8-10. 
Odnosząc te wątki do polskiej współczesności, nie przewidziałem przede wszystkim dwóch rzeczy. Dokonującego się na naszych oczach renesansu wizerunku historyka „strażnika narodowych wartości” oraz towarzyszącego mu myślenia utopijnego. Tak bowiem skłonny jestem interpretować program realizowanej przez zwolenników „dobrej zmiany” polityki historycznej. Mam na myśli wyłaniający się z szeregu wypowiedzi idealny obraz narodowej przeszłości, odwołujący się do karykaturalnego przedstawienia PRL jako jawnej lub zakamuflowanej „okupacji radzieckiej" i przeciwstawiania jej wreszcie w pełni niepodległej i suwerennej Polski obecnej. Nie muszę dodawać, że dla jego uprawomocnienia wykorzystuje się jako nosicieli owych „prawdziwie niepodległościowych” wartości odpowiednio spreparowane biografie żołnierzy wyklętych. Generalnie w ostatnim czasie najnowsza historia Polski jest „brzemienna” w cuda, czego dowodzą choćby pojawiające się w oficjalnych enuncjacjach władzy antykomunistyczne powstanie z lat 1945-1963 czy przybierające znamiona „cudowności” „rozmnożenie się” wspomnianych żołnierzy wyklętych².

\section{1}

W artykule Pomorskiego interesujące mnie wątki pojawiają się w różnych częściach jego wywodów, warto zatem na początku dokonać ich roboczej systematyzacji. Odwołując się do ustaleń z zakresu neuronauki, lubelski metodolog wzbogaca znaną nam dobrze po okresie fascynacji konstruktywizmem tezę, że przeszłość nie istnieje dla nas obiektywnie, ale zawsze jest „ontologicznie i epistemologicznie społecznie wykreowana" (wytłuszczenie - J. P.). Jego zdaniem, debaty wokół historii najnowszej są niejako skażone iluzją obiektywizmu. Uświadomienie sobie tego faktu winno być punktem wyjścia do poważnej refleksji nad miejscem historii w dyskursie publicznym. Dalej Pomorski podkreśla, że zabierając głos w debacie historycznej - my historycy akademiccy - powinniśmy pamiętać o dwóch odmiennych „gramatykach” rządzących naszym myśleniem i zachowaniem: społecznej praktyce badań historycznych i społecznej praktyce politycznej, i za każdym razem mieć świadomość, w jakiej roli występujemy. Wreszcie w kolejnych partiach artykułu pojawia się, przywoływana za Piotrem Sztompką, kategoria kapitału społecznego, który Pomorski definiuje jako specjalny, niematerialny rodzaj aktywów, jakie dana wspólnota posiada. Jest on, idąc tropem rozważań lubel-

2 Temat ten pozostawiam dalej na marginesie, wymagałby on bowiem odrębnego potraktowania. Jako próbę podsumowania dotychczasowych debat na temat historii najnowszej i wskazanie celów nowej polityki historycznej można uznać dużą część tekstów opublikowanych w najnowszym numerze „Biuletynu IPN” 2017, nr 1-2. Periodyk ten zastąpił wychodzące wcześniej pismo „Pamięć.pl”. 
skiego metodologa, synonimem wspólnie podzielanych wartości, idei i przekonań, w interesującym mnie kontekście, odnoszących się do narodowej przeszłości.

Wspomniane trzy konstrukty: iluzja obiektywizmu, wizja dwóch gramatyk rządzących naszym myśleniem oraz idea kapitału społecznego mają stanowić swoiste założenia wstępne, w których ramach Pomorski pragnie rozważać rolę historyka akademickiego. Istnieje takie powiedzenie: nie podobaja ci się wnioski, sprawdź zatożenia. Spróbuję pójść tą drogą.

Generalnie wszystkie przywołane wyżej założenia wydają mi się tezami przynależącymi do kategorii wishful thinking. Wbrew nadziejom Jana Pomorskiego duch obiektywizmu i związana $\mathrm{z}$ nim integralnie wiara w historię prawdziwa, widoczne są do tej pory w dużej części środowiska historyków akademickich, nie mówiąc już o architektach nowej polityki historycznej. W światooglądzie polskich badaczy przeszłości, szczególnie, co paradoksalne, dziejów najnowszych (celowo używam tu kategorii spopularyzowanej przez J. Pomorskiego) do dziś z trudem mieści się przekonanie, że historia z natury rzeczy jest pluralistyczna, składają się nań różne punkty widzenia, każdorazowo jej wizja pozostaje w ścisłym związku z klimatem epoki itd. Oni po prostu wierzą w mit historii prawdziwej, jedynej, stusznej. Idą w pewnym sensie drogą, cytowanego przez Pomorskiego Umberto Eco, narracyjnego kreowania rzeczywistości prawdziwszej niż sama rzeczywistość. Nie potrafią zrozumieć tego subtelnego rozróżnienia, które pojawia się w rozważaniach Pomorskiego, na homo historicus - sprawcę Historii i homo metahistoricus - obserwatora zajmującego się refleksją na dziejami. Te dwie role albo im się mylą, albo w ogóle ich sobie nie uświadamiają.

Podobnie rzecz wygląda w odniesieniu do dwóch gramatyk - praktyki badań historycznych i praktyki politycznej. Wspomniane rozróżnienie budzi moje wątpliwości z kilku powodów. Po pierwsze, owa dystynkcja jest nagminnie kwestionowana w debacie publicznej czy szerzej - w komunikacji międzykulturowej i nie widzę możliwości zaradzenia temu stanowi rzeczy. Po drugie, jest ona szczególnie trudna do utrzymania w dyskusjach dotyczących dziejów najnowszych, wyjątkowo silnie, z oczywistych powodów, zakorzenionych we współczesności. Po trzecie, kłóci się ona ze zdroworozsądkową wiedzą psychologiczną i socjologiczną, które podpowiadają, że w życiu społecznym występujemy często w różnych rolach, nie zawsze je sobie uświadamiając $c^{3}$.

3 Moim zdaniem, dzieje się tak nawet jeśli poczynimy dystynkcję między refleksyjną czy odruchową partycypacją w różnych praktykach społecznych a profesjonalnie i wspólnotowo kontrolowaną realizacją praktyki profesjonalnej. Teoretycznie, rygory tej ostatniej pozwalać powinny jedynie na minimalne, co najwyżej, odstępstwa od standardów naukowości. 
Chętnie przyjmuję postulat dbania przez historyków akademickich o rodzaj historycznego kapitału społecznego. Rodzą się jednak pytania - w jaki sposób miałby on być konstruowany oraz co powinno być jego fundamentem? Dzisiejszy spór o historię najnowszą nie jest, czego większość akademickich badaczy jest w pełni świadoma, jedynie sporem o metody czy interpretację źródel, jest sporem aksjologicznym. Wybierane przez nas wartości, z natury rzeczy, często wzajemnie się wykluczają albo podkładamy pod nie odmienne treści. Jednym z przykładów może być wolność i jej granice. Aleksander Smolar przenikliwie zauważył ostatnio:

Czy nasza wolność obejmuje także przeszłość? Czy przeszłość może być domeną wolnego wyboru? Czy wszystko możemy wymyślać. Kim jesteśmy? Skąd pochodzimy? Jeżeli pominiemy problem prawdy, to czy nie obowiązuje nas jakaś elementarna solidarność, choćby z najbliższymi? Nawet jeżeli, przede wszystkim jeżeli, zginęli śmiercią tragiczną z powodu swojego pochodzenia? Jeżeli manipulowanie własną przeszłością uznać za objaw wolności nie tylko w skali jednostkowej, to wtedy przeszłości nie ma, wszystko jest możliwe ${ }^{4}$

Czy rzeczywiście znaleźliśmy się w świecie, w którym w odniesieniu do przeszłości wszystko jest możliwe? Czy można bez konsekwencji kwestionować tysiące stron napisanych o Jedwabnem oraz rezultaty IPN-owskiego śledztwa i dowodzić, że powojenne zeznania świadków są niewiarygodne, bo zostały wymuszone przez pracowników Urzędu Bezpieczeństwa? Czy dopuszczalne jest w odniesieniu do ekspozycji Muzeum II Wojny Światowej, bez zapoznania się z dokumentacją i nie oglądając wystawy, twierdzić, że prezentuje ona antypolski punkt widzenia? $?^{5}$ To tylko dwa przykłady, spektakularnie pokazujące to, co się stało z historią najnowszą w Polsce w ostatnim czasie, dodam na marginesie, nie bez udziału akademickich historyków ${ }^{6}$.

\section{1}

Celem artykułu Jana Pomorskiego, jeśli dobrze zrozumiałem jego intencje, jest szeroko rozumiana obrona miejsca naukowej refleksji w debacie nad historią najnowszą. W wielu miejscach podąża on drogą Robina Collingwooda, krytykującego

4 A. Smolar, Bezpieczne miejsce, „Gazeta Wyborcza” 15-16.X.2016/ tekst z Księgi przyjaciót „Zeszytów Literackich" dla Barbary Toruńczyk.

5 Wspomniane przykłady można traktować nie tylko jako dowody narastającego woluntaryzmu w stosunku do przeszłości, ale także w kontekście boju o prawdę, w rozumieniu: prawda jest obiektywna, a obiektywna jest nasza, bo od nas pochodzi. Uwagę tę zawdzięczam Wojciechowi Wrzoskowi.

6 Jako spektakularne przykłady takiej postawy można uznać, przygotowane na zlecenie Ministerstwa Kultury i Dziedzictwa Narodowego, dwie recenzje wystawy przygotowanej przez Muzeum II wojny światowej, autorstwa Piotra Niwińskiego i Jana Żaryna. 
historyków nożyczek i kleju i pragnącego odnaleźć uniwersalne uzasadnienie dla wiedzy historycznej. Anglosaski historyk pisał:

Kiedy myślimy o historii jako li tylko rzemiośle, pracy, fachu czy zawodzie, ciężko usprawiedliwić naszą egzystencję jako historyków. Cóż historyk może zrobić dla ludzi poza uczynieniem z nich historyków, takich samych jak on? Na czym polega korzyść $z$ takiego postępowania? Czyż nie jest to błędne koło, które spowoduje przepełnienie szeregów tej profesji i wyprodukowanie źle opłacanego „intelektualnego proletariatu” spoconych nauczycieli? Jeżeli historia jest tylko zawodem, mnożenie historyków jest bezcelowe, lecz jeśli historia jest uniwersalnym ludzkim dążeniem, zwiększanie liczby historyków jest zasadne. Jeśli faktycznie zachodzi druga z wymienionych wyżej możliwości, to na świecie jest tyle samo historyków, co ludzi i pytanie nie brzmi: „Czy jestem historykiem ?”, lecz „jak dobrym historykiem mogę się stać ?”

W dobie utraty przez historyków „rządu dusz” w kreowaniu dominującego w społeczeństwie obrazu przeszłości, jest to obrona niewątpliwie zasadna i potrzebna, ale czy skuteczna? Pomorski pisze ciekawie o pulapkach, jakie czekają na historyka dziejów najnowszych, zwraca uwagę na niebezpieczeństwa prezentyzmu, poprawności politycznej, wskazuje na ambiwalencje tkwiące w polityce pamięci. Trudno nie przyznać mu racji. Pragnie uwrażliwić środowisko na niedostatki teorii i pułapki politycznego zaangażowania badacza. Przyświeca mu intencja, abyśmy wszyscy stali się Collingwoodowskimi dobrymi historykami, bardziej świadomymi swoich społecznych ról. Lubelski metodolog silnie podkreśla związki między poznawczymi i społecznymi celami historiografii. Rysuje przed czytelnikiem wizję dziejopisów trafnie rozpoznających gramatykę historii, w postaci prawidłowości, wyższego porządku czy struktury, $\mathrm{w}$ tym bowiem widzi przedmiot poznania historiografii, a zarazem receptę na uwolnienie nas od przygodności Historii.

Współczesny historyk dziejów najnowszych, zdaniem Pomorskiego, to także budowniczy wspólnego, społecznego kapitału społecznego w dziedzinie historii, kreujący pozytywne relacje w ramach wspólnoty, oparte o poczucie lojalności, zaufania i solidarności. To wreszcie wnikliwy obserwator, nie bagatelizujący społecznych emocji, starający się je zrozumieć i uwzględnić w praktyce badawczej.

7 R. George Collingwood, Filozofia historii, „Sensus Historiae” 2016, t. XXIV, s. 26. 


\section{IV}

Zarysowana przez Pomorskiego wizja jest niezwykle pociągająca, ambitna i pouczająca. Jako głos wypływający ze środowiska akademickich historyków spełni z pewnością swoje zadanie. Czy stanowi ona jednak wystarczające remedium na szereg negatywnych zjawisk dotyczących form obecności historii w przestrzeni publicznej? Mam wątpliwości. Wynikają one przede wszystkim z faktu, że używając terminologii Autora, to z czym mamy obecnie do czynienia w Polsce, to stosowane na niespotykaną od 1989 r. skalę zawłaszczanie przez jedną opcję polityczną wspólnego społecznego kapitału w dziedzinie historii, a tym samym pozbawianie nas historycznego bezpieczeństwa ontologicznego. W rezultacie historia najnowsza przestała być światem z trudem budowanego kompromisu, a stała się polem bitwy. W starciu tym, sądzę, wbrew nadziejom wyrażanym pośrednio przez Jana Pomorskiego, to nie historycy będą mieli głos rozstrzygający. 